\title{
The learning ability of Portuguese small family businesses
}

\section{António Fernandes}

School of Technology and Management, Instituto Politécnico de Bragança, Campus de Santa Apolónia, 5300-253 Bragança, Portugal

E-mail: antoniof@ipb.pt

\author{
Ana Maria Ussman* \\ Business and Economics Department, \\ Universidade da Beira Interior, \\ 6200 Covilhã, Portugal \\ E-mail: aussman@ubi.pt \\ *Corresponding author
}

\begin{abstract}
The learning ability of a firm is often cited as a necessary feature for its longevity. This ability has a greater impact on family businesses, given their characteristics. This research analyses the learning ability of Portuguese small family businesses. The research is based on an empirical study with primary data collected from a multiple case study of 22 firms. The results indicate that firms have some learning ability but on a small scale. The results also show that this learning capacity is almost absent from the design of firms' operations and employees and is especially related to the owner-manager and the relationship established with the environment.
\end{abstract}

Keywords: small family business; learning ability; Portugal.

Reference to this paper should be made as follows: Fernandes, A. and Ussman, A.M. (2013) 'The learning ability of Portuguese small family businesses', Int. J. Entrepreneurship and Innovation Management, Vol. 17, Nos. 1/2/3, pp.105-123.

Biographical notes: António Fernandes is a Professor at the Polytechnic Institute of Bragança in Portugal. He is a doctoral student at the University of Beira Interior, Portugal, being in the process of developing a thesis entitled 'The importance of tax benefits for companies in the region of the interior'. $\mathrm{He}$ is a partner of a consulting firm and provides consultancy services in the areas of accounting, information technology and investment in Northern Portugal.

Ana Maria Ussman is a Professor at University of Beira Interior, Portugal, and her research interests are related with family businesses. 


\section{Introduction}

According to Birdthistle (2008), small and medium-sized family businesses employ millions of people and generate a considerable amount of wealth in the world. The situation is similar in Portugal. The Portuguese Family Business Association and IFERA (2003) estimate that more than $70 \%$ of all Portuguese firms are family-owned. Given the relative importance of this group of firms in the economy, it will be important for those companies to have the knowledge and skills necessary for business development and continuity.

However, the contribution of family businesses to GDP and employment rates is generally lower than that of non-family businesses (IFERA, 2003).

Some researchers suggest this may be due to the fact that family firms are more risk adverse than non-family firms because their owners are concerned not only about the financial return, but also with the socio-emotional wealth obtained through the company (Gomez-Mejia et al., 2007). The owners of family firms see potential gains or losses of socio-emotional wealth as their primary reference in managing the company (Gomez-Mejia et al., 2007). A possible cause for this risk aversion is the fact that family businesses have most of their wealth concentrated in a single company, unlike other shareholders who invest in multiple companies (Gomez-Mejia et al., 2011). Other researchers share this opinion. Naldi et al. (2007) suggest that family members become risk adverse as their ownership in the firm increases. Family firms are viewed as conservative (Sharma et al., 1997). Founders are afraid of failure, so they become more conservative in their decisions; they want to preserve their venture as an inheritance. However, Zahra et al. (2004) argue that it depends on the family business culture. Some families have a long-term commitment and this can increase their entrepreneurial activities. This behaviour enables firms to increase their longevity, allowing them to devote the necessary resources to innovation and risk taking, thereby promoting entrepreneurship (Zahra et al., 2004).

The lack of innovation is also an important issue related to family businesses' competitiveness. If innovation is the essence of the entrepreneur at the launching of the new venture (Schumpeter, 1934), it seems that he loses this characteristic later on. According to Zahra et al. (2004) the founder dominates the organisation and the decisionmaking process for years, which limits innovative ideas. However, Lumpkin et al. (2010) have a different opinion - they state that as radical innovation has a very long pay-off, sometimes more than 10 years, if the family business has a long-term orientation it is possible that family firms could be more innovative. As family firms are long-term oriented and a long-term orientation is more consistent with innovation, then family businesses can be more innovative. This idea coincides with Zahra et al. (2004) who state that family businesses pursue continuity and are patient regarding their investments related to new business and technologies.

Innovation and risk-taking are important issues but are not the only ones related to competitiveness and continuity in family businesses. Another issue that has been associated with firms' competitiveness/sustainability but has received little attention in the context of family businesses is the ability to learn.

Smith (2008) considers the ability of a company to build knowledge upon its experience, as the most valuable asset and also the one most ignored. According to 
Branson (2008), and Slater and Narver (1995), the ability to learn faster than competitors may be the only source of sustainability and competitive advantage. In fact, the difficulties for individuals and organisations are accentuated in turbulent environments, with economic scenarios characterised by increasing competition where globalisation, mergers, acquisitions and job insecurity are always present (Bratton, 2001; Nyhan et al., 2004). Schein (1996) states that the difficulties in creating a learning organisation focus on concepts such as 'resistance to change', 'human nature' or 'failure of leadership'. Companies that are successful in maintaining their competitiveness have learned to read the change not as a single event, but as an ongoing process, which is necessary to remain at the forefront of customer needs (Shrivastava, 1983; Birdthistle, 2008).

Birdthistle (2008) examined the ability of Irish family SMEs to learn, and concluded that Irish firms are increasingly dependent on the skills and commitment of a few employees, which poses risks of continuity. Without a sufficient number of people with appropriate skills, the ability of family SMEs to remain competitive and grow is threatened. The opposite results were found by Sorenson et al. (2009). Based on research into 405 family SMEs, Sorenson et al. (2009) conclude that due to their special qualities, family businesses have more potential to be considered learning organisations. Nordqvist and Melin (2010) also suggest that family businesses have advantages as they accumulate in-depth and unique knowledge of products, markets or industry over generations. As the evidence is contradictory, research remains to be done.

So the questions are:

- Are family businesses learning organisations?

- What are the variables that most influence the learning process in family businesses?

The purpose of this paper is to find out if small family businesses in Portugal have the potential to be classified as learning organisations.

The research is considered innovative due to two reasons:

- There is a lack of research on Portuguese family businesses. Most of these businesses, regardless of size, prefer to keep their anonymity (IFERA, 2003).

Simultaneously, there is a widespread belief about family businesses which is mainly based on negative prejudices about how these companies operate (IFERA, 2003).

- The learning capacity of companies has been mainly investigated in large companies, so the size of the companies in the sample is another innovative factor since few studies have been made of SMEs (Howorth and Ali, 2001; Bracci and Vagnoni, 2011).

We adopt a qualitative methodology. The research is based on 22 Portuguese small family businesses located in the north of the country. To measure the learning capacity of the family businesses we used an adaptation of the questionnaire by Templeton (2000), a questionnaire he had previously tested.

This study is divided into five sections; after the introduction, Section 2 presents the literature review and Section 3 presents the methodology; data analysis is in Section 4. Finally, Sections 5 and 6 present the conclusions and implications of this research. 


\section{Literature review}

\subsection{The organisation's learning capacity}

The concept of organisational learning emerged between 1960 and 1970, when the challenge of change reached its climax in the minds of most managers (Yeo, 2005). Yeo argues that the notion of technological progress was seen as the panacea for organisational transformation in the 1970s. From this point of view, managers and consultants were seen as people who played the doctor with the responsibility of curing diseases and promoting companies' health (Schein, 1996).

Brown and Keep (1999) define a learning organisation as one where people continually expand their capacity to create the results they truly desire, where new and renewed patterns of thinking are developed, where collective aspiration is set free and where people are continually learning, and especially, learning together.

According to Sinkula (1994), organisational learning is a three-step process that includes information acquisition, information dissemination and shared interpretation. The acquisition of information can occur through direct experience, the experiences of others, or organisational memory (Slater and Narver, 1995). The disclosure of information increases its value as each fraction of information can be viewed in a broader context by all stakeholders who are able to give feedback, which supposes enlargement or modification, and offers new prospects for the sender (Glazer, 1991). Shared interpretation inside organisations is also considered critical to the success of partnerships and alliances in the learning organisation (Mohr and Spekman, 1994).

Nyhan et al. (2004) believe that the two major strains in terms of organisational learning are:

- The need to build a tangible organisational structure, but also and simultaneously to promote an organisational culture based on intangible values and meanings.

- The need to promote cohesion and collective efficacy/organisational strategies and at the same time promote an environment conducive to individual initiative, autonomy and self-development.

In Figure 1, the two sets of tensions are represented on a continuous basis.

On the horizontal axis, we have the contrasting demands between (on the left) the need to formalise and to make explicit and transparent, that is, to make tangible and (on the right) the need to pay attention to the informal, the subjective and the tacit - the intangible. There is an immaterial culture, whose guiding principles are shared values and collective meanings to deal with changing contexts and processes within the firm and with the outside, but simultaneously, a concrete structure supposes the application of rules and limits to ensure stability, adding a tangible value to the firm.

On the vertical axis, we have the need to design learning strategies in order to construct a corporate identity and to define performance targets, and simultaneously foster personal responsibility and initiative based on a sense of individual identity. Organisational development aims to transform individual strengths in collective actions in the interest of the organisation (Smith, 2008). Yeo (2005) considers that the collective learning will result in improved organisational performance and in a competitive advantage for the organisation. The individual possesses personal initiative (professional identity) and responsibility (discipline). Sinkula (1994) considers individuals as a 
cornerstone in the development of a learning organisation. According to Crossan et al. (1999), at its basic level, individual learning is understanding the similarities and differences in patterns and possibilities. Workers must perform functions more autonomously, they must monitor their own production and behaviour to adapt to change, they need to solve problems, they have to take initiatives and think creatively in order to achieve more effective solutions and better meet customer expectations (Brown and Keep, 1999). Nyhan et al. (2004) stated that a key to promotion of a learning organisation is to organise work with a view to human development. Garavan (1997) argues that human development promotes collective learning.

Figure 1 Organisation of innovation and learning

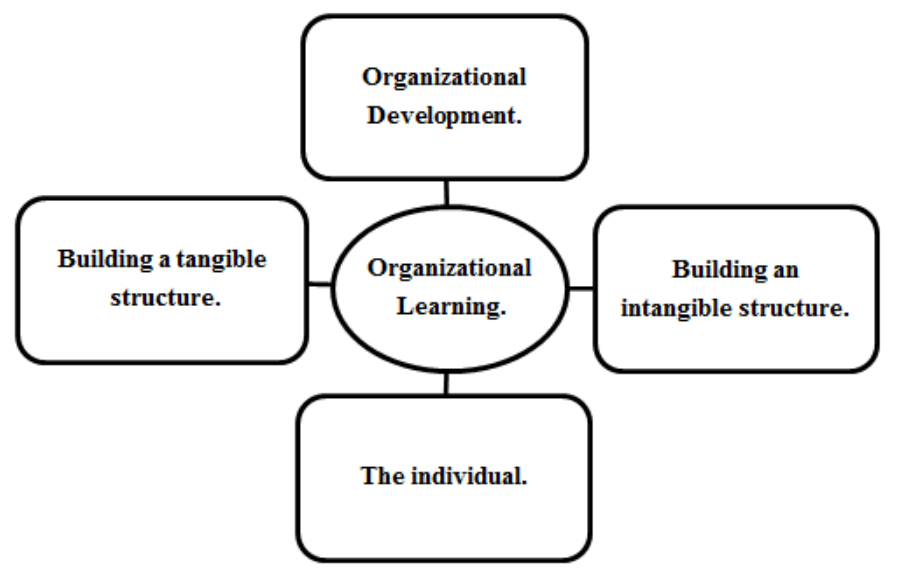

Source: Adapted from Nyhan et al. (2004)

On the left of the figure, we have tangible characteristics, which can be articulated with the characteristics on the right, the intangibles such as human knowledge, thoughts and feelings. Measuring both sides in articulation allows us to evaluate the firm's learning ability. When these relationships are based on mutual trust and responsibility, they provide the conditions for personal and tacit shared knowledge, a prerequisite for collaborative organisational learning.

Another key issue is that everybody must find a common meaning in the objectives of the organisation. This facilitates a cohesive organisational identity which does not conflict with the interests of individuals, allowing employees to gain personal and professional benefits while working for collective goals. Nyhan et al. (2004) state that the learning capacity serves as a vision enabling organisations to understand their contexts, the meaning of their practice and explore their own unique situations to meet economic and social objectives for the benefit of all.

Prugsamatz (2010) also stated the importance of the organisational culture in creating a learning capacity. The study conducted by Prugsamatz (2010) shows that an organisation's cultural practices are the basis of its own learning capacity, which is transmitted to the outside through the mission, leadership and structure of alliances. Thus, the critical challenge for any business is to create the combination of factors (organisational culture and climate) that can maximise knowledge to create customer value in dynamic and turbulent markets (Small and Irvine, 2006). 
The relationship between firm size and organisational learning is unclear. Hendry (1991) and Garavan (1997) argue that small firms may have distinct advantages in terms of building a learning organisation. However, Brown and Keep (1999) state that SMEs may have more difficulties than large companies in creating an organisational culture and climate, as well as more difficulties in providing the full range of learning opportunities for the development of broad professional competences. According to Brown and Keep (1999), small businesses have obvious difficulties in providing a full range of learning opportunities for the development of competences. For these authors, it is critical to think of the organisation addressing issues related to social inclusion, participation and society's needs.

\subsection{The learning capacity of the family business}

Chua et al. (1999, p.25) define "The family business as a business governed and/or managed with the intention to shape and pursue the vision of the business held by a dominant coalition controlled by members of the same family or a small number of families in a manner that is potentially sustainable across generations of the family or families." According to Sharma (2004), the fundamental dimension in considering family businesses is the important role of the family in the business, defining the vision, providing resources and unique capabilities and controlling the business. Others consider that this strong relationship between family and business may be somewhat negative. Brenes et al. (2011) state that family businesses result from the interaction between the business system and the family system which sometimes causes conflicts, making management more complex. This complexity happens because management of the family business has to do with business and also with family (Sorenson, 1999; Arrègle and Mari, 2010).

In this research, we define a small family business as a small company where the majority of ownership is held by a family, and some family members are employed in the company or the family is represented on the board of directors. The family is considered a kinship group of people related by blood or marriage or similar relationships.

An essential issue when thinking about family businesses is succession. According to Chua et al. (1999), family businesses are unique because of their specific pattern of ownership, management and succession and the way this influences their goals, strategy and structure, as well as the way in which each of these points is developed, designed and implemented. Gomez-Mejia et al. (2011) state that the desire to transfer control of the business to the next generation is one of the main factors separating family businesses from non-family firms. However, it is not enough to transfer management to the next generation, it is important that internally the business creates conditions for sustainability.

Family businesses, just like non-family businesses, that want to survive in a rapidly changing world and highly competitive markets must adopt a philosophy of organisational learning, as well as a clearly-defined strategy, through which to develop new approaches to create value for customers. As stated by Crossan et al. (1999) and Templeton et al. (2009), organisational learning can be conceived as the main vehicle for the company's strategic renewal, and family businesses need this continual renovation. When we take family businesses, the learning capacity of the organisation must be analysed considering the relationship between business and family. The firm's growth is sustained by the successive challenges that the company poses to the family and the 
challenges that new generations bring to the family business (Ussman, 2004) but also by the capacity to learn that the company creates over time.

As learning capacity takes time to be developed, family businesses could be in a better position to take advantage of the long-term investments made in them. As suggested by Anderson (2003) and by Sharma and Manikutty (2005), families have more distant horizons than other shareholders, suggesting that management should invest in long-term projects and wait for results. Ussman (2004) also believes that the family business is always thinking about future generations even if this is done without a formalised plan. This long-term orientation is consistent with development of a learning capacity.

However, for companies that aspire to a long life, Sharma and Manikutty (2005) consider that changes in the environment require multiple actions including an adequate portfolio of products and the disposal of unproductive resources. But change is complicated in family firms. As Salvato et al. (2010) write, even when families realise that change is needed, it is difficult to implement due to the fear of losing family harmony. One strong value in family firms is respect for their ancestors and to introduce change is to disrespect them. The challenge of family business culture is to be responsive to environmental change according to the aspirations of the current generation and, at the same time, respect the values of the founder.

Another topic usually related to learning capacity is personal initiative. Zahra et al. (2004) suggest that innovation in family businesses depends on their culture. An organisational culture oriented to the inside might inhibit a family firm's capacity to explore innovative methods and practices. Externally oriented organisational cultures actively search market trends that can provide new insights. According to Nordqvist and Melin (2010), families are reluctant to exit from areas where the family firm has been operating, in some cases, for generations. There is an emotional attachment to the past that prevents innovation. According to Zahra et al. (2004), employees are also limited in their initiatives. Zahra et al. (2004) stresses that centralisation in the hands of family members induces rigidity in the firm, creating limits for the exchange of ideas among employees.

The initial question remains: are small family businesses learning organisations?

Based on Figure 1 we propose a research model in Figure 2, which aims to present an adaptation for small family businesses.

The informality of processes in small firms is well known and documented (Bridge et al., 1998). When the small firm is also a family business we also have the informality of relationships within the family but also between family members and employees.

Gomez-Mejia et al. (2011) state that in family businesses communication with employees is essentially informal, through impromptu meetings and social gatherings, rather than formal systems. The authors also consider that the use of social networks in the recruitment process reduces information asymmetries and ensures a better fit with organisational values. The lower dependence on formal control increases the importance of a company's culture as a determinant of behaviour (Zahra et al., 2004).

In small family businesses, the intangible elements of culture have a greater weight than the material elements given the greater informality of procedures, greater seniority of employees, greater trust between family members and between family members and employees, commitment and loyalty, the family's reputation in the community and the know-how transmitted across generations, etc. (Ussman, 2004). All these elements are 
intangible but strong enough to characterise the family business. Accordingly, in our model the right side of the figure - intangible culture - is more important in creating learning capacity.

Figure 2 Organisation of learning in small family businesses

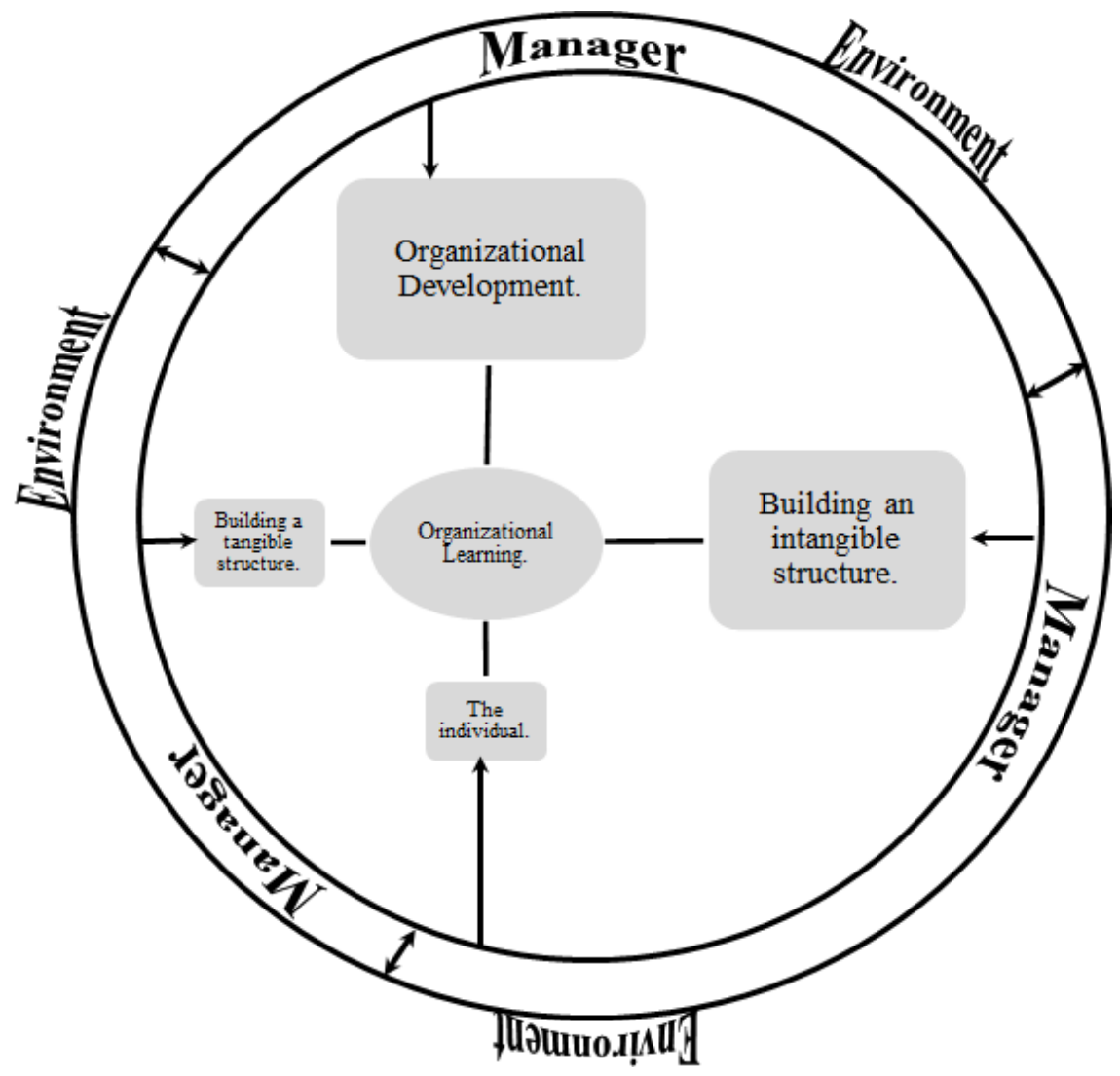

Similarly, the organisation is more important than the individuals. Relationships within the group are strengthened in family businesses, as mentioned by Arrègle and Mari (2010) or, as pointed out by Ussman (2004), the collective family goals override the particular objectives. The managers of family businesses see their firms as a legacy to be passed on to the next generation, not as wealth to be consumed during their lifetime (Gomez-Mejia et al., 2011). The family as a whole is worth more than a generation or a family member. And this seems true for both family members and employees. Teamwork achievements matter more than individual achievements. Employees also behave on a group basis. Autonomy is high at management level but is difficult at employees' level. Martin and Lumpkin (2003) found that autonomy is strong in the first generation but decreases as more family members are involved in management as they need consensus to manage. Casillas and Moreno (2010) also found that at later stages, when family business develops and some non-family executives are hired they may feel their autonomy constrained somewhat. 
Any of these features is highly dependent on the personality of the owner-manager. Zahra et al. (2004) stated that the founder controls the firm and the decision process. Bracci and Vagnoni (2011), and Zahra et al. (2004) consider that family businesses outperform non-family businesses due their distinct and unique features and characteristics. The authors call these features and capabilities 'family sense'. Gomez-Mejia et al. (2011) call this feature 'socio-emotional wealth' and define it as central, enduring and exclusive to the owner, influencing everything the company does. In subsequent generations, as ownership and management are controlled by the same person or group of people, this enables owner-managers to continue to impose a strong personal touch, more than in non-family businesses (Ussman, 2004). As issues like culture or organisation design are dominated by the owner-manager, we cannot think about the learning capacity of the family business without taking this person into account.

Everything is influenced by the environment surrounding the firm (Gomez-Mejia et al., 2011). Each firm is unique in its internal variables but is also unique in the relationship it establishes with the outside and in the way its manager perceives the external atmosphere. The environment itself changes over time and across the country. Moreover, the environment provides a source of networks that can bring knowledge to the firm. Sorenson et al. (2009) concluded that a strategic advantage for family businesses lies in strong family networks that benefit the business.

These two factors, owner-manager and environment, not present in Figure 1 are added according to the literature review. Nonaka and Toyama (2003), and Sinkula (1994) also suggest these two variables. The model outlines the relationships of the four sets of tensions in the family business, remaining constantly connected to the decisions of the owner-manager and all of this depending on the surrounding environment.

\section{Methodology}

\subsection{Design}

This research is based on 22 small family businesses selected in the municipality of Bragança, northern Portugal. Twenty-two owner-managers and 22 employees, one manager and one employee per company, were surveyed. Questioning simultaneously the owner-manager and an employee per firm has the objective of data triangulation. As Dymock and McCarthy (2006) say, the questionnaire for the owner-manager intends to reveal the company's vision and strategy in developing a culture of learning, while the questionnaire for the employee aims to explore how employees perceive the reality of that vision and the impact of strategies. Dymock and McCarthy (2006) concluded that according to their hierarchical level, people have a different perception of learning capacity so it seems important to have at least two different opinions per firm.

\subsection{Selection of cases}

As in Portugal there is no database of family businesses, the research is based on an accidental sample of firms. The cases were selected from a consultancy and accountancy firm's list of clients who meet the criteria of being small and family businesses. The questionnaires were sent via electronic mail to each family business explaining the 
objectives of the research and asking for collaboration. Later, on a visit to each firm, the questionnaires were completed by the owner-manager and by an employee.

\subsection{Data collection instrument}

Slater and Narver (1995) recognise the difficulty in measuring organisations' learning ability. They point out that a key challenge will be to develop measures of learning outcomes specifically to assess whether an organisation is in fact a learning organisation. Thus, in preparing the questionnaire we followed the work of Templeton (2000). As his questionnaire is already tested, we followed most of his questions. The questions are in three groups; local operations of the company, company employees and company management.

The questionnaire sent to the owner-manager had 38 questions. Eight questions were related to their role in the firm, nine were related to operations, ten were about employees and the remaining questions were related to management. The questionnaire for employees consists of 32 questions. The first two questions were related to their role in the firm, nine questions were related to operations, ten questions refer to the employees themselves and 11 questions were related to management.

In the questions about learning capacity, owner-managers and employees could answer yes, if the sentence corresponded exactly to the situation in the firm, no, if the sentence did not apply and sometimes if it might happen occasionally.

\subsection{Data analysis}

Since this is an exploratory research and the questionnaire by Templeton (2000) accepted a nominal scale, the data was subjected to triangular analysis in order to have the perception of the owner-manager but also that of employees. The data were plotted on charts for better visualisation, for each of the areas considered - the company's operations, employees and management. To check whether there were statistically significant differences between employees and owner-managers' perceptions about the firms' learning capacity we used the non-parametric Wilcoxon W.

\section{Results and discussion}

\subsection{Sample}

Table 1 shows some characteristics of the firms. With the exception of two cases, companies are first generation family businesses which mean that the age of the firm is the same as the length of time the current owner-manager has been in charge. So far, most of these companies have probably not needed to develop specific strategies for family involvement and succession processes nor had an opportunity to assess the success or failure of these processes (Arrègle and Mari, 2010). Note that some authors, notably Bracci and Vagnoni (2011) consider succession as one of the most critical processes in the life cycle of family businesses.

There is low employee turnover in family businesses. The cases in this study show that, on average, employees remain with the company 5.64 years and almost all of that time they remain in the same position, especially when firms are small. 
Business activities are above all retail, wholesale and catering and accommodation.

Table 1 Characterisation of firms

\begin{tabular}{lccc}
\hline & Sales & Employees & Total assets \\
\hline Mean & $3,210,389 €$ & 8.41 & $481,811 €$ \\
Std. deviation & $8,750,006 €$ & 10.017 & $554,707 €$ \\
Minimum & $20,830 €$ & 1 & $66,944 €$ \\
Maximum & $40,148,075 €$ & 43 & $2,264,523 €$ \\
\hline & Age of company & Number of years & Number of years working in \\
& (years) & working in the company & company in this \\
\hline Mean & 11.82 & 11.55 & 11.55 \\
Std. deviation & 7.588 & 7.781 & 7.781 \\
Minimum & 2 & 2 & 2 \\
Maximum & 29 & 29 & 29 \\
\hline
\end{tabular}

\subsection{Dimensions of learning ability}

Figure 3 shows a summary of the answers concerning firms' operations and the way this contributes to the firm's learning capacity.

Figure 3 Owner-managers and employees' responses on the company's local operations

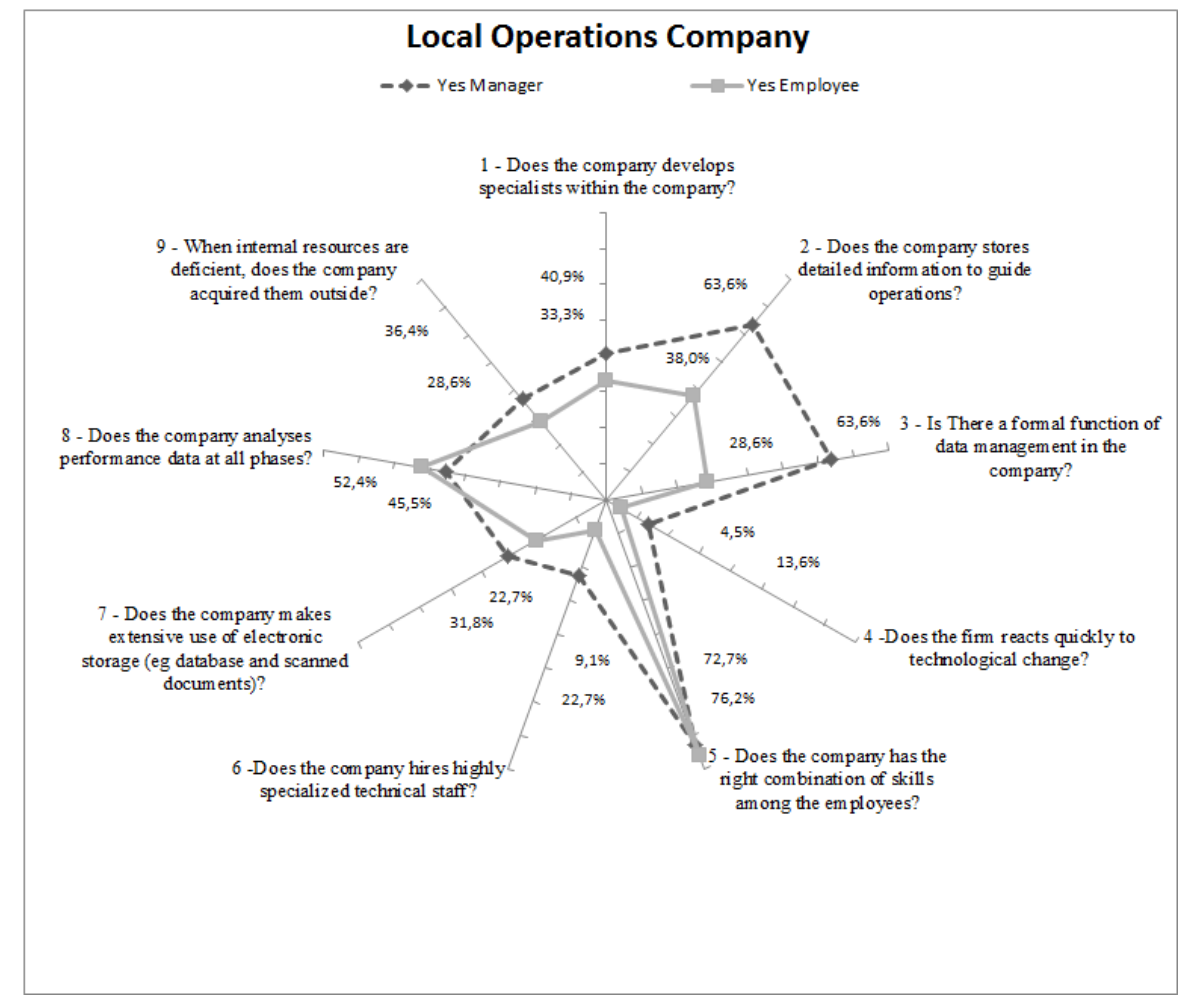


Analysis of Figure 3 shows several aspects that deserve to be mentioned. First of all, the ability to learn is relatively weak since only three variables in a total of 9 have percentages of yes above $50 \%$. Learning capacity is based on the diverse competencies of employees, on information management and on employee assessment. We can see that owner-managers have a more optimistic vision of the firm's learning ability than employees. However, these differences are not statistically significant according to the Wilcoxon W test (Table 2).

This analysis suggests that in the items related to operations there is no capacity for learning. The firms' operations are not organised to provide learning capacity.

Table 2 Test Statistics Wilcoxon W

\begin{tabular}{lccc}
\hline & $\begin{array}{c}\text { 18-When employees } \\
\text { need specific } \\
\text { information, do they } \\
\text { know they will get it? }\end{array}$ & $\begin{array}{c}\text { management keep } \\
\text { track of the important } \\
\text { variables of } \\
\text { organisational } \\
\text { performance? }\end{array}$ & $\begin{array}{c}30-\text { Are } \\
\text { employees } \\
\text { encouraged to } \\
\text { indicate new ideas } \\
\text { for work? }\end{array}$ \\
\hline Mann-Whitney U & 166,000 & 154,000 & 164,500 \\
Wilcoxon W & 419,000 & 407,000 & 417,500 \\
Z & $-2,007$ & $-2,451$ & $-2,006$ \\
Asymp. Sig. (2-tailed) & 0.045 & 0.014 & 0.045 \\
\hline
\end{tabular}

Figure 4 analyses the answers given by owner-managers and employees on how employees contribute to organisational learning.

Here again, owner-managers have a more positive perception than employees about the learning capacity but the differences are only statistically significant when we consider employee access to information. The ability to learn seems weak as only four of the ten variables have percentages greater than $50 \%$. As we are evaluating learning capacity based on employees, this represents a waste of resources as Brown and Keep (1999) defend a learning strategy based on everyone related to the firm. However, this result is consistent with the ideas of Zahra et al. (2004) who referred to the limited initiative given to non-family members in family businesses. Despite the poor learning ability based on employees, there is a focus on communication between employees, information sharing, information access and employee knowledge. The importance given to items related to information is interesting, as Sinkula (1994) defines organisational learning based on information - information acquisition, information dissemination and shared interpretation. Glazer (1991) also pointed out the importance of communication and shared information in learning processes.

Finally, from this figure, in the perceptions of owner-managers and employees, employees are apparently more conducive to learning than operations were, but the situation is not very encouraging.

Figure 5 allows us to analyse the responses of owner-managers and employees on their perception of the firm's management as related to learning capacity.

The owner-managers have a more positive perception of the learning capacity than employees have and now with statistically significant differences in two variables (Wilcoxon W test, Table 2) - management keeps track of organisational performance and employees are encouraged to indicate new ideas. It seems that the ability to learn is 
mainly based on the owner-manager. The owner-manager is alert to competitors but also to business partners, he is pro-active, learns directly and uses that information.

Figure 4 Owner-managers and employees' responses on the company's employees

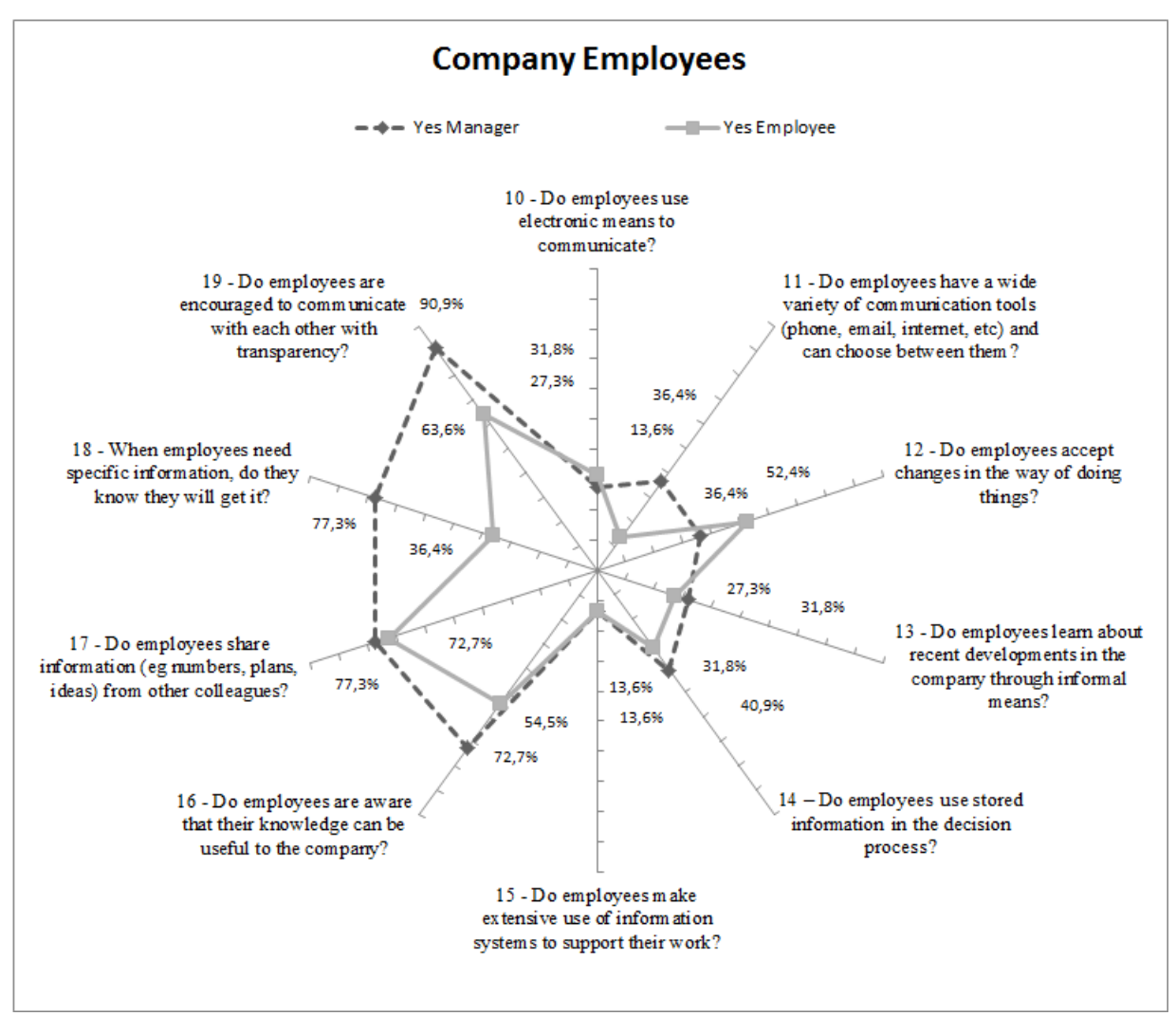

As these are small and medium-sized firms, the importance given to the owner-manager in the learning process both by him/herself and employees is not surprising. In small and medium-sized family businesses the owner-manager plays a decisive role. Sharma (2004) refers to the central role of the owner-manager in the family business but also Gomez-Mejia et al. (2011) draws attention to the dominant role of the owner-manager.

Taking the responses of management and employees together, the appreciation is positive only in the items related to management.

In the following figure, we group the responses according to the model shown in Figure 2, in order to evaluate learning capacity, but now systematised in immaterial culture versus tangible structure, individual versus organisational development and the role played by the owner-manager and the environment.

In an analysis of the model's dimensions, there is the same concentration on intangible culture as on tangible structure, which contradicts the assumption advanced in the research model that family businesses would favour the immaterial aspect in the process of organisational learning. The answers (38\% versus 37\%) show no significant differences between the tangible elements of the structure and the intangible elements. In fact, in this sample, data about formality and informality in family businesses do not 
corroborate the ideas of Gomez-Mejia et al. (2011) or Zahra et al. (2004). The results are however consistent with the idea advanced by Nyhan et al. (2004), who speak of the need to promote simultaneously and evenly tangible and intangible elements in the organisational culture to promote the organisation's ability to learn. Formality and informality are balanced; the problem is the low values attributed by respondents.

Figure 5 Owner-managers and employees' responses about management

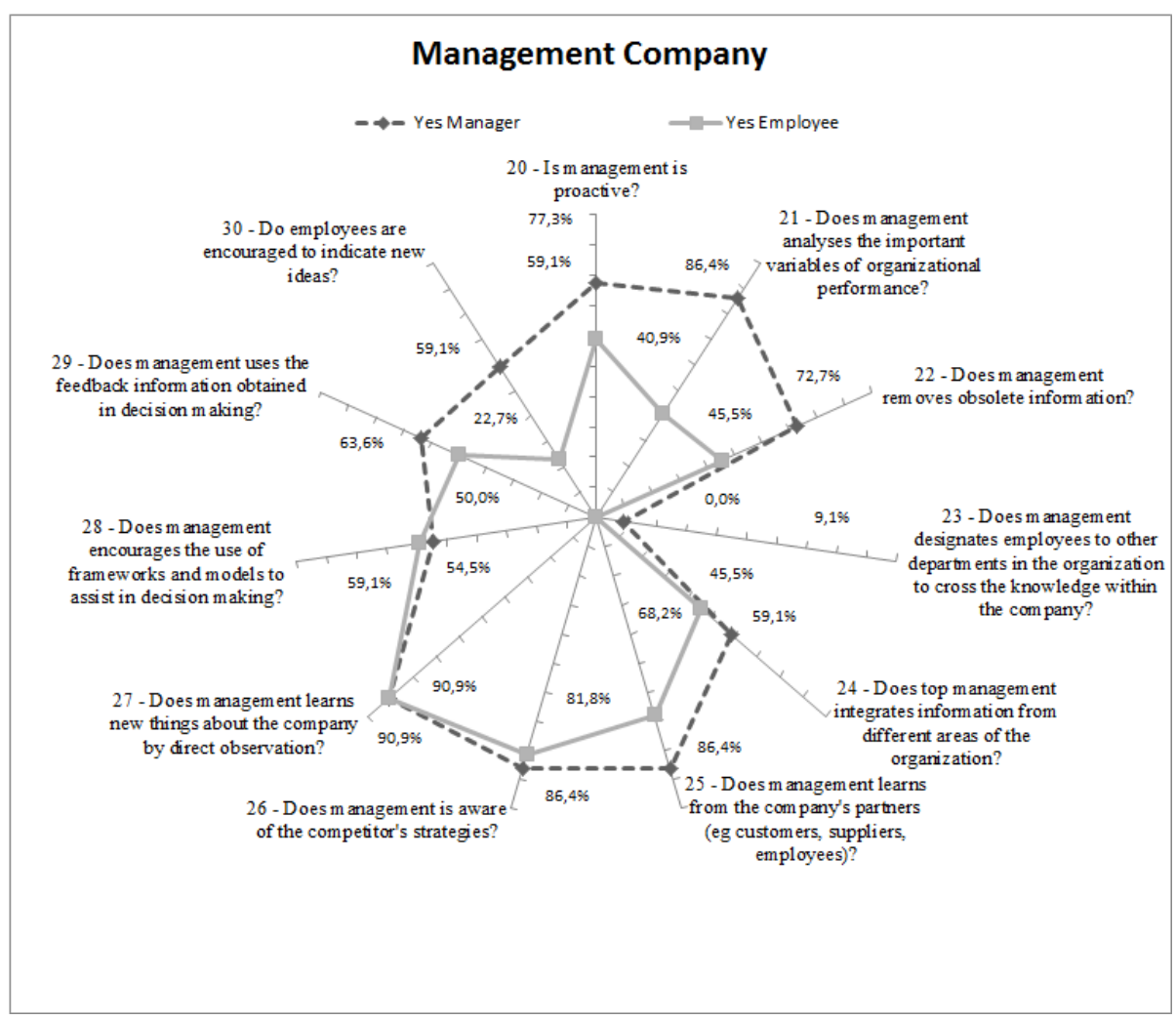

In relation to the dimension of individual versus organisational development, the results are different. For owner-managers and employees, the results indicate that the collective is more important than the individual. The difference in evaluation is not very important but it corroborates the expectations of the research model according to which family firms valued the collective against the individual.

The model puts a strong emphasis on the role played by the owner-manager in the family business. All the owner-managers in the sample are founders. This helps to understand the values obtained in the dimension of manager $(62 \%)$. As stated by Ussman (2004), when ownership is associated with management, a situation which is usually strongest with the firm's founder, the importance of his role is really visible.

As expected, the evaluation of owner-managers and employees is positive in relation to the dimension of environment (74\%), which reveals that companies pay attention to the environment and how this interferes with their ability to learn. Firms are responsive to demands and constraints from outside. 
Figure 6 Learning capacity perception of owner-managers and employees

Group of questionnaire respondents together

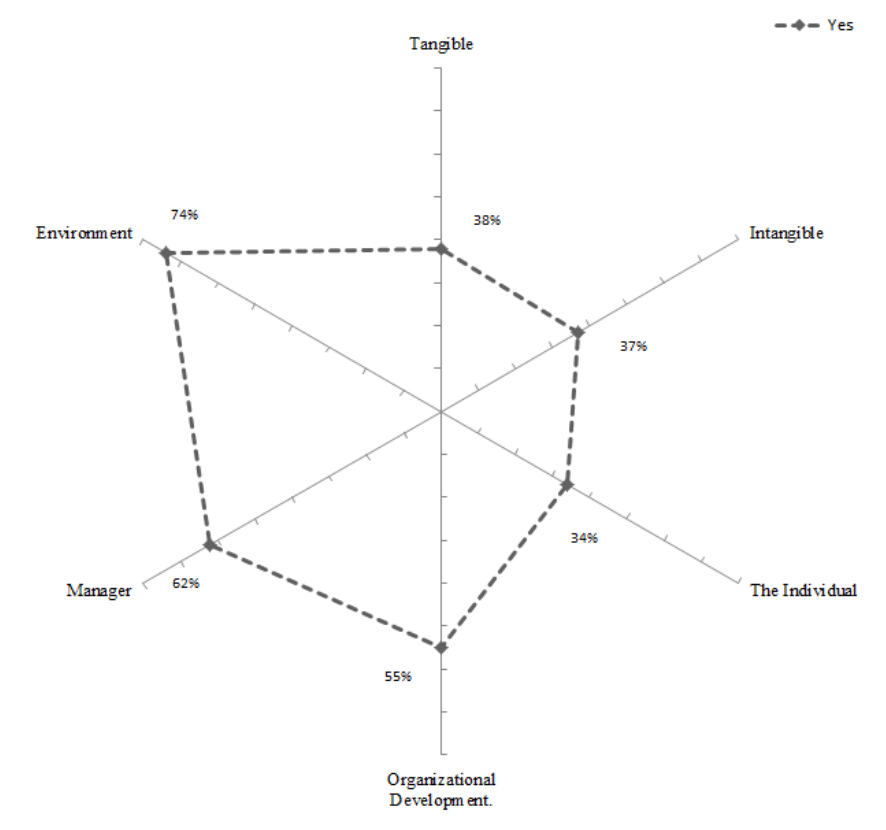

\section{Conclusions}

The objective of this paper was to analyse the learning ability of small family businesses. This ability is considered essential to ensure the continuity of the firm through generations. These companies are central to economic development and it is essential that company management possesses the knowledge to develop the business in ideal conditions. This requires not only investment in fixed assets but also in intangible assets to sustain the business.

However, the results are not very encouraging. Answering the questions that guided this investigation, it seems that:

1 in general, Portuguese small family businesses are not very successful in creating learning atmospheres

2 inside the firm, the learning capacity is mainly the domain of the owner-manager

3 it seems that firms are alert to the external atmosphere and to the possibilities to learn from it. 
When we analyse the data in relation to the company's operations, employees and management, there seems to be learning ability only in management. Owner-managers act in a way that creates learning possibilities but they do not exploit the possibilities offered by their employees nor design firms' operations in order to create learning opportunities. This can pose a serious problem when the time for succession arrives - the firm is not prepared to go on if the owner-manager does not transfer his knowledge to the successors. It is essential that companies enhance their learning ability at employee and operation levels to avoid becoming too dependent on one person.

An interesting result is that the items related to information - access to, sharing information, management of or feedback, received a positive evaluation from both employees and owner-managers. This suggests that information is an important issue in small family businesses and can be a useful tool to facilitate the learning capacity of these firms.

When the results are analysed regarding the dimensions of the research model, there seems to be some learning capacity related to organisational development, management and the environment.

Given these results, it is considered that the firms in this sample present evidence of weak learning ability.

It is recognised, however, that the results must be viewed with care, as being case studies they do not allow generalisation.

\section{Implications}

\subsection{Managerial implications}

It is often said that small family businesses have limited resources; this research shows how one valuable asset, the employees, are not properly used in creating knowledge within the company. This is a waste of resources that small firms cannot afford.

A result that deserves to be noted is the high percentage of sometimes responses, which reveals a lack of consistency in the operation and management of these companies. When employees and owner-managers answered sometimes in such high percentages, this means that the firms' practices do not follow a uniform pattern over time. Consequently, there is a lack of standardisation of practices which is typical of entrepreneurial management. It should be remembered that all the companies surveyed are SMEs and are in the phase of the founder who runs the firm on a day-today basis, far removed from professional management routines and institutionalised practices.

The ability to learn is concentrated in the owner, practically one person dominates the process. The firm runs a big risk as everything can be lost if succession is not prepared in time. At least knowledge can be transmitted to the next generation.

\subsection{Research implications}

Since there is relatively little research on the learning capacity of small family businesses, it is necessary to do more research with different methodologies in order to check for consistency in the results obtained. To allow generalisation of the conclusions, for example, it would be necessary to carry out quantitative work, with a larger sample of family businesses and questioning more people per company. 
A specific research topic is how the entrepreneur transfers his knowledge to his successor. This issue is particularly important since research indicates that the ability to learn focuses on the owner-manager.

Accidentally, the firms in this research were first generation family firms and this situation may have had some influence on the results. It raises the question about the next generations and their role in the learning ability of small family businesses. With the dispersion of ownership and management among brothers and sisters, will family members maintain the centralism or act in such a way that allows employees to participate in the learning ability of the family business?

Finally, it would be interesting to research methods to create and sustain employees' learning ability and thus increase the learning ability of the company. Are there differences between family businesses and non-family businesses in the way employees participate in the learning process?

\section{References}

Anderson, R. (2003) 'Founding-family ownership and firm performance: evidence from the Sandamp; P 500', The Journal of Finance, Vol. 58, No. 3, pp.1301-1327.

Arrègle, J. and Mari, I. (2010) 'Avantages ou désavantages des entreprises familiales?', Revue Française de Gestion, Vol. 1, No. 200, pp.87-109.

Birdthistle, N. (2008) 'Family SMEs in Ireland as learning organizations', The Learning Organization, Vol. 15, No. 5, pp.421-436.

Bracci, E. and Vagnoni, E. (2011) 'Understanding small family business succession in a knowledge management perspective', Knowledge Creation Diffusion Utilization, Vol. 9, No. 1, pp.7-36.

Branson, C.M. (2008) 'Achieving organizational change through values alignment', Journal of Educational Administration, Vol. 46, No. 3, pp.376-395.

Bratton, J.A. (2001) 'Why workers are reluctant learners: the case of the Canadian pulp and paper industry', Journal of Workplace Learning, Vol. 13, Nos. 7/8, pp.333-344.

Brenes, E.R., Madrigal, K. and Requena, B. (2011) 'Corporate governance and family business performance', Journal of Business Research, Vol. 64, No. 3, pp.280-285.

Bridge, S., O’Neill, K. and Cromie, S. (1998) Understanding Enterprise, Entrepreneurship and Small Business, Macmillan Press, London.

Brown, A. and Keep, E. (1999) 'Competing perspectives on workplace learning and the learning organisation', TSER Network Forum for European Research in Vocational Education and Training (FORUM), at the University of Evora, Portugal, Vol. 44, pp.1-29.

Casillas, J. and Moreno, A. (2010) 'The relationship between entrepreneurial orientation and growth: the moderating role of family involvement', Entrepreneurship \& Regional Development, May-July, Vol. 22, Nos. 3-4, pp.265-291.

Chua, J.H., Chrisman, J.J. and Sharma, P. (1999) 'Defining the family business by behavior', Entrepreneurship: Theory and Practice, Summer, Vol. 23, No. 4, pp.19-39.

Crossan, M.M., Lane, H.W. and White, R.E. (1999) 'An organizational framework: learning from intuition to institution', Academy of Management Review, Vol. 24, No. 3, pp.522-537.

Dymock, D. and McCarthy, C. (2006) 'Towards a learning organization? Employee perceptions', The Learning Organization, Vol. 13, No. 5, pp.525-537.

Garavan, T. (1997) 'The learning organization: a review and evaluation', The Learning Organization, Vol. 4, No. 1, pp.18-29.

Glazer, R. (1991) 'Marketing in an information-intensive environment: strategic implications of knowledge as an asset', Journal of Marketing, Vol. 55, No. 4, pp.1-19. 
Gomez-Mejia, L.R., Cruz, C., Berrone, P. and Castro, J. (2011) 'The bind that ties: socioemotional wealth preservation in family firms', The Academy of Management Annals, Vol. 5, No. 1, pp.653-707.

Gomez-Mejia, L.R., Haynes, K.T., Núñez-Nickel, M., Jacobson, K.J.L. and Moyano-Fuentes, J. (2007) 'Socio-emotional wealth and business risks in family-controlled firms: evidence from Spanish olive oil mills', Administrative Science Quarterly, Vol. 52, No. 1, pp.106-137.

Hendry, C. (1991) 'International comparisons of human resource management: putting the firm in the frame', The International Journal of Human Resource Management, Vol. 2, Nos. 2-3, pp.415-441.

Howorth, C. and Ali, Z.A. (2001) 'Family business succession in Portugal: an examination of case studies in the furniture industry', Family Business Review, Vol. 14, No. 3, pp.231-244.

IFERA (2003) 'Family businesses dominate: international family enterprise research academy (IFERA)', Family Business Review, Vol. 16, No. 4, pp.235-240.

Lumpkin, G.T., Brigham, K.H. and Moss, T.W. (2010) 'Long-term orientation: implications for the entrepreneurial orientation and performance of family businesses', Entrepreneurship and Regional Development, Vol. 22, Nos. 3-4, pp.241-264.

Martin, W. and Lumpkin, T. (2003) 'From entrepreneurial orientation to family orientation: Generational differences in the management of family businesses', Paper presented at the 22nd Babson College Entrepreneurship Research Conference, Babson College, USA.

Mohr, J. and Spekman, R. (1994) 'Characteristics of partnership success: partnership attributes, communication behavior, and conflict resolution techniques', Strategic Management Journal, Vol. 15, No. 2, pp.135-152.

Naldi, L., Nordqvist, M., Sjöberg, K. and Wiklund, J. (2007) 'Entrepreneurial orientation, risk taking, and performance in family firms', Family Business Review, Vol. 20, No. 1, pp.33-48.

Nonaka, I. and Toyama, R. (2003) 'The knowledge-creating theory revisited: knowledge creation as a synthesizing process', Knowledge Management Research and Practice, Vol. 1, No. 1, pp.2-10.

Nordqvist, M. and Melin, L. (2010) 'Entrepreneurial families and family firms', Entrepreneurship \& Regional Development, May-July, Vol. 22, Nos. 3-4, pp.211-239.

Nyhan, B., Cressey, P., Tomassini, M., Kelleher, M. and Poell, R. (2004) 'European perspectives on the learning organization', Journal of European Industrial Training, Vol. 28, No. 1, pp.67-92.

Prugsamatz, R. (2010) 'Factors that influence organization learning sustainability in non-profit organizations', The Learning Organization, Vol. 17, No. 3, pp.243-267.

Salvato, C., Chirico, F. and Sharma, P. (2010) 'A farewell to the business: championing exit and continuity in entrepreneurial family firms', Entrepreneurship \& Regional Development, May-July, Vol. 22, No. 3-4, pp.321-348.

Schein, E.H. (1996) 'Three cultures of management: the key to organizational learning', Sloan Management Review, Fall, Vol. 38, No. 1, pp.9-20.

Schumpeter, J. (1934) The Theory of Economic Development, Harvard University Press, Cambridge.

Sharma, P. (2004) 'An overview of the field of family business studies: current status and directions for the future', Family Business Review, Vol. 17, No. 1, pp.1-36.

Sharma, P. and Manikutty, S. (2005) 'Strategic divestments in family firms: role of family structure and community culture', Entrepreneurship Theory and Practice, Vol. 29, No. 3, pp.293-311.

Sharma, P., Chrisman, J. and Chua, J. (1997) 'Strategic management of family business: past research and future challenges', Family Business Review, Vol. 10, No. 1, pp.1-35.

Shrivastava, P. (1983) 'A typology of organizational learning systems', Journal of Management Studies, Vol. 20, No. 1, pp.7-28.

Sinkula, J.M. (1994) 'Market information processing and organizational learning', Journal of Marketing, Vol. 58, No. 1, pp.35-45. 
Slater, S.F. and Narver, J.C. (1995) 'Orientation and the learning organization', Journal of Marketing, Vol. 59, No. 3, pp.63-74.

Small, A. and Irvine, P. (2006) 'Towards a framework for organizational learning', The Learning Organization, Vol. 13, No. 3, pp.276-299.

Smith, P.a.C. (2008) 'The learning organization turns 15: a retrospective', The Learning Organization, Vol. 15, No. 6, pp.441-448.

Sorenson, R.L. (1999) 'Conflict management strategies and family and business outcomes in family businesses', United States Association for Small Business and Entrepreneurship San Diego, pp.14-17.

Sorenson, R.L., Goodpaster, K.E., Hedberg, P.R. and Yu, A. (2009) 'The family point of view, family social capital, and firm performance: an exploratory test', Family Business Review, Vol. 22, No. 3, pp.239-253.

Templeton, F.G. (2000) Development of the Organizational Learning Construct and Measure, Auburn University, Auburn, Alabama.

Templeton, G.F., Schmidt, M.B. and Taylor, G.S. (2009) 'Managing the diffusion of organizational learning behavior', Springer Science + Business Media, Vol. 11, No. 2, pp.189-200.

Ussman, A.M. (2004) Empresas Familiares, (1.a Edição.), Edições Sílabo, Lda.

Yeo, R.K. (2005) 'Revisiting the roots of learning organization: a synthesis of the learning organization literature', The Learning Organization, Vol. 12, No. 4, pp.368-382.

Zahra, S.A., Hayton, J.C. and Salvato, C. (2004) 'Entrepreneurship in firms: a resource-based analysis of the effect of organizational culture', Entrepreneurship: Theory and Practice, Summer, Vol. 28, No. 4, pp.363-382. 